$\left.\begin{array}{l}\text { Sournals } \\ \text { INTERNATIONAL JOURNAL OF } \\ \text { ORGANIZATIONAL LEADERSHIP }\end{array}\right) \begin{gathered}\text { INDUSTRIAL } \\ \text { MANAGEMENT } \\ \text { INSTITUTE }\end{gathered}$

\title{
Scientific impact of social science scholars with senate positions at Turkish public universities in 2014
}

\author{
Aziz Kutlar, Abidin Öncel, Ali Kabasakal* \\ Department of Econimics, Sakarya University, Sakarya, Turkey
}

\begin{abstract}
Keywords:

Scientific Impact, Turkish Universities, Administration, Social Science Scholars, Academic Performance

\section{Received}

12 April 2016

This paper investigated the scientific impact of social science scholars with senate positions at Turkish public universities in 2014. The number of social science scholars within the given year with senatorial duties was 967 . They had 812 WoS publications and 2868 WoS citations. Public finance administration, law, archeology, politics, art history, and theology departments had the lowest scientific impact while economics administration, social services, psychology, and geography departments had the highest scientific impact. The scientific contribution of such scholars to their universities merits discussion.
\end{abstract}

Received in revised form

12 August 2016

Accepted

18 August 2016

Correspondence:

kabasakal@sakarya.edu.tr

(C)AIMI Journals

Quality in higher education has an important role in human, social, and economic development through human capital accumulation. Therefore, countries are trying to enhance the quality of their higher educational systems. There are some organizations which determine the ranking of world universities. During the last several years, Academic Ranking of World Universities which is known as Shanghai ranking, the Times Higher Education World University Rankings, and the Quacquarelli Symonds World University Rankings provide some data for choosing international universities (Millot, 2014). The University Ranking by Academic Performance 
(URAP) Center which is affiliated to the Middle East Technical University in Turkey has been calculating the rankings of Turkish international universities since 2009. Even though, some variables beyond the research indicators have been suggested to rank the universities (Bergseth, Petocz \& Dahlgren, 2014; Lukman, Krajnc, \& Glavi, 2010), the ranking organizations' methodology has not changed significantly.

Ranking organizations have begun calculating the ranks according to academic fields such as social sciences, arts, and humanities; however, none of Turkish universities are listed in universities' rankings in relavent fields during 2014-2015. This study evaluated the scientific impact of social science scholars with senate positions at Turkish public universities. It was worthy to investigate the scientific impact of academic characteristics of the senate which its purpose was to regulate and reshape all academic affairs. The chief executive officer of a Turkish public university and the rector are appointed for a maximum of four academic terms by the president of the Turkish Republic. Before their appointment, the entire body of faculty members including assistant professors, associate professors, and full professors should vote the full professor candidates for rectorating. After evaluating and reducing the six candiadates with the highest vote to three, the council for higher education presents the president the list of universities and therefore the process is completed. After appointing three to five full professors as vice rectors for four year terms, the rector appointed three elected full professor candidates for each dean position at colledge and the higher council completes the appointment.

The rector also appoints the managers of the faculty members to the universities, institutes, schools, and vocational schools for three terms. All these administrators serve as natural members of the senate, the ultimate responsibility for university's governing body, which has the authority to make and regulate the rules of all academic affairs such as promotions at public universities. In addition to these natural members, there is also a faculty representative in the senate elected by the faculty members of each college. There are also non-senator administrators such as department heads, vice deans, and vice managers in universities which their scholarly activities or performances are not evaluated in this study.

All the members of the senate, excluding the rector, may be reappointed or re-elected indefinitely after serving their three or four-year terms. All the senate members, including the rector, are expected to perform scholarly activities in addition to their administrative duties. The only waiver they get is from the ten-hour weekly teaching requirement that each faculty member must fulfill. After having completed their terms, senators return to their regular faculty positions and continue their regular academic duties. In fact, all assistant and associate professors including senators must perform research and produce their publications in order to be promoted and associated to full professors; however, full professors have almost no incentive to do research or publication.

In 2015, there were 183 universities in Turkey which 74 of them were private. Eighty-four percent of public universities have social science senators with publications in WoS. This study includes the scholarly activities and competency of social science senators at 84 Turkish public universities in 2014 based on their number of WoS publications and WoS citations. Evaluating the number of publications and citations of all scholars with executive positions in Turkish public universities is not possible; we have therefore limited our study to social science 
senators such as educational sciences. Thus, WoS publications and citations of those senators will be examined.

\section{The Literature Review}

The available empirical studies for evaluating the efficiency of higher education mainly employ data envelopment analysis, (DEA), stochastic frontier, and panel regression analysis. According to Coelli, Rao, and Battese (1998) DEA is considered as a widespread method for measuring efficiency of non-profit institutions such as hospitals, schools, and universities. Some recent educational studies (Abbott \& Doucouliagos, 2003; Afonso \& Santos, 2004; Ahn, Arnold, Charnes, \& Cooper, 1989; Athanassopoulos \& Shale ,1997; Avkiran, 2001; Calhoun \& Hall, 2003; Castano \& Cabanda, 2007; Cherchye \& Abeele, 2005; Flegg \& Allen, 2007; Johnes, 2006; Salerno, 2002; Worthington \& Lee, 2008) in different parts of world in Australia, Germany, England, Philippines, and the United States are also worth pointing out.

$\mathrm{Ng}$ and Li (2000) and Joumady and Ris (2005) represented an exception, as they work with a set of countries. They also introduced a new method for using the gained competence during the undergraduate years and the competence required by current jobs as output methods. Ruiz, Segura, and Sirvent (2015) evaluated the educational performance of Spanish public universities in terms of undergraduate studies following the Bologna Declaration. They reported that not only the results of universities' achievement but also the availability of resources was important from university administrators' perspective. The results indicated that the university administrators could set the most convenient performance targets. Agasisti and Dal Bianco (2009) analyzed the effects of teaching reforms in Italy. The reforms introduced in 1999 changed the entire organization of university courses. They initially defined the production process of higher education which consists of various inputs that combine to produce outputs. They measured this effect by employing data envelopment analysis (DEA) and Malmquist indexes (MI) which suggested that both technical efficiency and production technology benefited from reforms. They claimed that Italian and European universities' challenges needed to be faced in a multi-task learning context. Avkiran (2001) conducted one of the first studies on efficiency of Australian universities based on the data obtained in 1995. The findings indicated that more universities were operating at decreasing returns to scale, suggesting the potential to downsize. Johnes and Yu (2008) also employed DEA to examine the relative efficiency of 109 Chinese universities' research production in 2003 and 2004. Therefore, output variables in the study measured the research impact and productivitywhile the input variables reflected the organizations' staff, students, capital, and resources. Their study evaluated whether geographical location, source of funding, and type of university had made any significant difference between higher education institutions. Their findings suggested that China's western regions had lower mean research efficiency than its coastal and central regions. The study focused on the efficiency of universities only in the outputs of the research. However, this study as a university research is essential for recognizing the spillover effects on local businesses and therefore could be considered as a key tool in developing regional economic.

Katharaki and Katharakis (2010) examined the efficiency of 20 Greek public universities through quantitative analysis. Their findings indicated inefficiency in terms of human resources 
management and also identified a clear opportunity to increase research activity and income. Their paper also discussed the process methodology which they used in their investigation and its potential to evaluate the efficiency of resource management by the public universities. This study contributes to the broader debate on reforming management and administration systems of universities in Greece. Zoghbi, Rocha, and Mattos (2013) utilized the scores of standardized tests as an output in order to estimate the efficiency of education production in Brazilian universities. They suggested that qualitative indicators such as occupation and long-term remuneration could better describe the contribution of education to human capital. Moreover, an intermediate result such as the obtained score in a standardized test can be regarded as one of the basic elements in human capital accumulation. Yaisawarng and $\mathrm{Ng}$ (2014) assessed the impact of the latest higher education reform on Chinese universities' performance during 2007-2009. The Chinese government allocated \$20 billion to 112 universities to promote research with an ultimate goal. This money acts as national catalyst for raising Chinese educational standards. The study investigated the data collected from two target groups of universities which were known as Project 211and non-Project 211 and had not received any funding. The results revealed that the reform had its intended effect on the Chinese universities. According to the results of study, the universities in Project 211 performed better on average than the non-Project 211 group. Administrative inefficiency was the key attribute of low productive efficiency. Their findings suggested that higher education reforms should be broadened to allow all university groups to enhance their research capabilities.

Celik and Ecer (2009) stated that accounting education is an effective element in finding out the companies' operational environment. They surveyed 45 Turkish public universities through applying DEA. Their study revealed that the universities in Turkey were successful in generating the most appropriate output and were usually applying their input components in the best way. The results of the study indicated that accounting education presented in higher education system of Turkey was generally influential. On a departmental basis, they realized that the departments of labor economics, public finance, and industrial relations were more influential departments. Public finance departments were the most influential ones while business administration departments were the most indifferent ones based on the resource usage. Their study showed that the correct uses of resources would produce more competitive and well-read accounting professionals. Daraioa, Bonaccorsi, and Simar (2015) claimed that university rankings are the subject of a paradox because the majority of social scientific experts blame them on theoretical- methodological grounds, the more attention they attain in policymaking and the media. They attempt to overcome four main issues of university rankings and emphasize the importance of investing in data integration and open data for research and policy-making at the European level. Their results provided some evidence to demonstrate performance issues and identify the current directions for improvement. G. Johnes and J. Johnes (2009) used a panel of data to estimate the multiproduct cost function of British higher education institutions. The panel approach which was used in this study permits estimation by means of a random parameter such as stochastic frontier production model that permits the effect on costs of inter-institutional differences in the cost function itself to be identified from inter-institutional differences in turnover. They reported the total average incremental cost of provision as well as its scale and scope. 


\section{Results}

Different frontier methods such as DEA and cost functions were used in some empirical studies to investigate the efficiency of Turkish universities. These studies evaluated various production units which were analyzed over multiple time periods; therefore, it was quite hard to compare and contrast our results to the findings of other previous studies. Nonetheless, it is important to note that the institutions' low level of efficiency in the southern zones compared to those ones in the northern zones is compatible with other studies. The statisitical population of this study consisted of social science senators at Turkish public universities during 2014. The total number of publications and citations in WoS were used to measure the senators' scientific impacts. Twenty- one different social science fields were used inthis study. In fact, the expertise of public universities' senators in different fields obstructed an even comparison. Therefore, we have limited our study to social science senators including educational sciences and their WoS publications and citations will be taken into consideration. Our study applied some statistical techniques, graphics, and correlations. At Turkish public universities in 2014, 3350 scholars were serving in senates. Among those senators only 2266 of them had a total of 25079 WoS publications and 1936 of them had a total of 155157 WoS citations. However, 15 443 of those citations were self-citations. In other words, 32.3 per cent of all the senators had no publications in WoS and 42.28 per cent of those senators had no citations. Each senator had on average almost 8 self-citations. There were 967 social science senators among those 84 public universities and only 273 of them had a total of 812 publications and only 130 of them had 2868 citations in WoS. Table 1 represents the profile of social science senators who have WOS publications.

Table 1

University Rankings of Publications \& Citations

\begin{tabular}{|c|c|c|c|c|c|c|c|c|c|c|c|c|c|}
\hline Institutions & WoS & ExCited & Cited & Pers & $\begin{array}{l}\text { Pers } \\
\text { WoS } \\
\end{array}$ & $\begin{array}{c}\text { Pers } \\
\text { WoS/ Pers }\end{array}$ & Institutions & WoS & ExCited & Cited & Pers & $\begin{array}{l}\text { Pers } \\
\text { WoS }\end{array}$ & $\begin{array}{c}\text { Pers } \\
\text { WoS/Pers }\end{array}$ \\
\hline Bogazici & 53 & 342 & $\begin{array}{c}36 \\
0\end{array}$ & 6 & 6 & 1.00 & Gebze Tech & 7 & 95 & 96 & 1 & 1 & 1.00 \\
\hline Harran & 46 & 626 & $\begin{array}{c}68 \\
6\end{array}$ & 9 & 5 & 0.55 & Sutcu Imam & 7 & 2 & 2 & 12 & 3 & 0.25 \\
\hline $\begin{array}{l}\text { Middle East } \\
\text { Tech }\end{array}$ & 35 & 86 & 95 & 4 & 4 & 1.00 & Makif Ersoy & 7 & 1 & 1 & 11 & 3 & 0.27 \\
\hline Ardahan & 28 & 41 & 60 & 7 & 3 & 0.42 & $\begin{array}{l}\text { Yildirim } \\
\text { Beyazit }\end{array}$ & 7 & 3 & 3 & 13 & 5 & 0.38 \\
\hline Aandolu & 27 & 96 & $\begin{array}{c}10 \\
0\end{array}$ & 11 & 5 & 0.45 & Karatekin & 6 & 6 & 6 & 8 & 3 & 0.37 \\
\hline Hacettepe & 26 & 43 & 45 & 14 & 9 & 0.64 & Sdemirel & 6 & 1 & 1 & 22 & 4 & 0.18 \\
\hline $\begin{array}{l}\text { H. Bektas } \\
\text { Veli }\end{array}$ & 26 & 133 & $\begin{array}{c}13 \\
8\end{array}$ & 13 & 5 & 0.38 & Ahievran & 5 & 0 & 0 & 5 & 2 & 0.40 \\
\hline Sakarya & 23 & 55 & 56 & 25 & 4 & 0.16 & Bulent Ecevit & 5 & 5 & 5 & 7 & 2 & 0.28 \\
\hline Yildiz Tech & 22 & 48 & 49 & 3 & 2 & 0.66 & Hititi & 5 & 0 & 0 & 7 & 5 & 0.71 \\
\hline Osmangazi & 20 & 38 & 40 & 10 & 7 & 0.70 & Nerbakan & 5 & 19 & 19 & 9 & 2 & 0.22 \\
\hline Akdeniz & 19 & 38 & 38 & 19 & 8 & 0.42 & Celal Bayar & 4 & 0 & 0 & 10 & 3 & 0.30 \\
\hline Duzce & 19 & 69 & 75 & 8 & 3 & 0.37 & Gaziantep & 4 & 6 & 6 & 9 & 4 & 0.44 \\
\hline Selcuk & 19 & 42 & 44 & 27 & 9 & 0.33 & Gaziosmanpasa & 4 & 8 & 8 & 6 & 2 & 0.33 \\
\hline Kocaeli & 18 & 15 & 15 & 11 & 4 & 0.36 & Karabuk & 4 & 1 & 1 & 9 & 2 & 0.22 \\
\hline $\begin{array}{l}\text { Mustafa } \\
\text { Kemal }\end{array}$ & 18 & 19 & 19 & 8 & 7 & 0.87 & Kastamonu & 4 & 1 & 1 & 8 & 3 & 0.37 \\
\hline Pamukkale & 18 & 22 & 22 & 20 & 8 & 0.40 & Uludag & 4 & 0 & 0 & 11 & 1 & 0.09 \\
\hline Onsekiz Mart & 16 & 19 & 19 & 20 & 6 & 0.30 & Yuzuncu Yil & 4 & 1 & 1 & 7 & 1 & 0.14 \\
\hline Izzet Baysal & 15 & 22 & 26 & 7 & 4 & 0.57 & Ataturk & 3 & 0 & 0 & 16 & 2 & 0.12 \\
\hline
\end{tabular}




\begin{tabular}{|c|c|c|c|c|c|c|c|c|c|c|c|c|c|}
\hline Sitki Kocman & 14 & 59 & 59 & 14 & 6 & 0.42 & Batman & 3 & 3 & 3 & 6 & 3 & 0.50 \\
\hline Cukurova & 13 & 16 & 16 & 13 & 6 & 0.46 & Dumlupinar & 3 & 6 & 6 & 9 & 3 & 0.33 \\
\hline Balikesir & 12 & 15 & 16 & 18 & 4 & 0.22 & Firat & 3 & 1 & 1 & 12 & 2 & 0.16 \\
\hline Gazi & 12 & 3 & 3 & 19 & 5 & 0.26 & Giresun & 3 & 0 & 0 & 12 & 3 & 0.25 \\
\hline $\begin{array}{l}\text { Adnan } \\
\text { Menderes }\end{array}$ & 11 & 136 & $\begin{array}{c}13 \\
8\end{array}$ & 11 & 4 & 0.36 & Kirklareli & 3 & 3 & 3 & 8 & 2 & 0.25 \\
\hline Dokuz Eylul & 11 & 13 & 14 & 19 & 4 & 0.21 & Korkut Ata & 3 & 1 & 1 & 5 & 1 & 0.20 \\
\hline Erciyes & 11 & 2 & 2 & 15 & 5 & 0.33 & Şirnak & 3 & 48 & 51 & 5 & 1 & 0.20 \\
\hline Aksaray & 10 & 118 & $\begin{array}{c}11 \\
9\end{array}$ & 11 & 5 & 0.45 & Koca Ocatepe & 2 & 10 & 10 & 21 & 2 & 0.09 \\
\hline $\begin{array}{l}\text { Sosyal } \\
\text { Bilimler }\end{array}$ & 10 & 65 & 80 & 2 & 1 & 0.50 & Inonu & 2 & 0 & 0 & 9 & 2 & 0.22 \\
\hline Marmara & 10 & 33 & 34 & 22 & 3 & 0.13 & Medeniyet & 2 & 1 & 1 & 7 & 2 & 0.28 \\
\hline Namik Kemal & 10 & 14 & 14 & 5 & 2 & 0.40 & 7 Aralik & 2 & 0 & 0 & 6 & 2 & 0.33 \\
\hline Şeyh Edebali & 9 & 8 & 8 & 10 & 2 & 0.20 & Trakya & 2 & 0 & 0 & 12 & 3 & 0.25 \\
\hline Istanbul & 9 & 37 & 37 & 21 & 4 & 0.19 & Tunceli & 2 & 0 & 0 & 7 & 1 & 0.14 \\
\hline Artklu & 9 & 23 & 27 & 6 & 1 & 0.16 & Usak & 2 & 0 & 1 & 11 & 1 & 0.09 \\
\hline Ankara & 8 & 26 & 27 & 12 & 4 & 0.33 & $\begin{array}{l}\text { Bilim Ve } \\
\text { Teknoloji }\end{array}$ & 1 & 3 & 3 & 3 & 1 & 0.33 \\
\hline Erzincan & 8 & 0 & 0 & 13 & 3 & 0.23 & Coruh & 1 & 0 & 0 & 10 & 1 & 0.10 \\
\hline Galatasaray & 8 & 14 & 14 & 6 & 3 & 0.50 & Bitlis Eren & 1 & 0 & 0 & 4 & 1 & 0.25 \\
\hline Kafkas & 8 & 0 & 0 & 8 & 2 & 0.25 & Bozok & 1 & 0 & 0 & 2 & 1 & 0.50 \\
\hline $\begin{array}{l}\text { Karadeniz } \\
\text { Tech }\end{array}$ & 8 & 3 & 4 & 12 & 6 & 0.50 & Erzurum Tech & 1 & 0 & 0 & 5 & 1 & 0.20 \\
\hline Mersin & 8 & 73 & 74 & 9 & 3 & 0.33 & Hakkari & 1 & 0 & 0 & 4 & 0 & 0.00 \\
\hline Nigde & 8 & 6 & 6 & 7 & 4 & 0.57 & Katip Celebi & 1 & 1 & 1 & 10 & 1 & 0.10 \\
\hline Bartin & 7 & 17 & 17 & 6 & 1 & 0.16 & Kirkkale & 1 & 0 & 0 & 10 & 1 & 0.10 \\
\hline Cumhuriyet & 7 & 40 & 40 & 21 & 4 & 0.19 & Rt Erdogan & 1 & 0 & 0 & 12 & 1 & 0.08 \\
\hline \multirow[t]{2}{*}{ Ege } & 7 & 1 & 1 & 7 & 7 & 1.00 & Yalova & 1 & 0 & 0 & 10 & 1 & 0.10 \\
\hline & & & & & & & Total & 812 & 2702 & 2868 & 967 & 273 & 0.28 \\
\hline
\end{tabular}

In Table 1, the WoS column provides the total number of WoS publications while ExCited column provides the total number of citations made by other scholars, and Cited column gives the number of total number of citations including self-citations. The coulumns such as Pers, PersWoS, and PersWoS/Pers provided the number of senators, the number of senators who had publications in WoS, and the ratio of the senators with WoS publications, respectively. Bogazici, which is considered one of the most prestigious Turkish public universities, was listed on the top. It is surprising that Harran University is listed as the second, even though it is a relatively young and not so popular university. Two scholars of Harran, T. Demir and Z. Şimşek had high-profile publications and hence the university is ranked as second. Middle East Technical and Ardahan also follow these universities. It is remarkable to mention that Ardahan University is considered as a newly established university and one of top ranked universities. Among Turkey's 109 public universities, only 84 of them had social science senators with WoS publications. Selcuk, Sakarya, Marmara, and Suleyman Demirel universities had the highest number of senators who specialized in social sciences. The number of publications which has been published by senators is the highest at Hacettepe, Selcuk, Akdeniz, and Pamukkale Universities. In social sciences senators, the persons who employed in Bogazici, Ege, Gebze Technical, and Middle East Technical universities had roughly the highest number of WoS publications. Each senator at Bogazici, Middle East Technical, and Gebze Technical had at least one WoS publication. Adiyaman, Ibrahim Cecen, Amasya, Bayburt, Bingol, Dicle, Gumushane, Igdir, Karamanoglu Mehmet Bey, Mimar Sinan Fine Arts, Alparslan, Ondokuz 
Mayis, Ordu, Siirt, Sinop, and Turk-Alman had 87 social science senators, and none of those 87 senators had any WoS publications.

Table 2 provides descriptive statistics of social science senators who conduct research in 21 fields.

Table 2

Descriptive Statistics of 21 Research Fields

\begin{tabular}{|c|c|c|c|c|c|}
\hline & Pers & WoS & Cited & ExCited & PersWoS \\
\hline Mean & 46.04 & 38.66 & 136.57 & 128.66 & 13.00 \\
\hline Median & 24 & 24 & 49 & 48 & 8 \\
\hline Maximum & 167 & 157 & 498 & 467 & 51 \\
\hline Minimum & 6 & 3 & 0 & 0 & 1 \\
\hline Std. Dev. & 47.18 & 44.54 & 172.04 & 161.60 & 14.03 \\
\hline Skewness & 1.41 & 1.54 & 0.99 & 1.01 & 1.54 \\
\hline Kurtosis & 4.02 & 4.27 & 2.58 & 2.69 & 4.32 \\
\hline Jarque-Bera & 7.91 & 9.81 & 3.62 & 3.68 & 9.90 \\
\hline Probability & 0.01 & 0.00 & 0.16 & 0.15 & 0.00 \\
\hline Sum & 967 & 812 & 2868 & 2702 & 273 \\
\hline Sum Sq. Dev. & 44522.95 & 39676.67 & 591981.10 & 522322.70 & 3938.00 \\
\hline Observations & 21 & 21 & 21 & 21 & 21 \\
\hline
\end{tabular}

As Table 2 demonstrates, the mean value of the senators is 46 while the mean value of senators with publications in $\mathrm{WoS}$ is 13 . Moreover, it shows that the standard deviation value for Pers is too high and distribution for social science senators is not normal. The obsrved results for WoS publications seemed the same. Furthermore, the value of standard deviation for the citations was considered too high. There was a subtantial difference between the maximum and minimum values. The high deviation for the citations was a result of the publication's acceptance. Table 3 shows the list of 21 research fields in social sciences and arts and humanities.

Table 3

Research Field Rankings of WoS Publications \& Citations

\begin{tabular}{|c|c|c|c|c|c|c|c|c|c|}
\hline Research Field & Pers & Pers $\%$ & WoS & WoS $\%$ & Cited & Cited $\%$ & Cited / WoS & PersWoS & PersWoS / Pers \\
\hline Theology & 167 & 17.27 & 12 & 1.48 & 2 & 0.07 & 0.16 & 9 & 0.05 \\
\hline Business & 154 & 15.93 & 115 & 14.16 & 216 & 7.53 & 1.87 & 51 & 0.33 \\
\hline Economics & 108 & 11.17 & 133 & 16.38 & 498 & 17.36 & 3.74 & 41 & 0.38 \\
\hline History & 75 & 7.76 & 34 & 4.19 & 17 & 0.59 & 0.50 & 20 & 0.26 \\
\hline Law & 69 & 7.14 & 3 & 0.37 & 1 & 0.03 & 0.33 & 3 & 0.04 \\
\hline Education & 68 & 7.03 & 157 & 19.33 & 257 & 8.96 & 1.63 & 38 & 0.55 \\
\hline Language & 56 & 5.79 & 34 & 4.19 & 5 & 0.17 & 0.14 & 17 & 0.30 \\
\hline Public Administration & 54 & 5.58 & 32 & 3.94 & 150 & 5.23 & 4.68 & 17 & 0.31 \\
\hline Tourism Management & 42 & 4.34 & 47 & 5.79 & 209 & 7.29 & 4.44 & 17 & 0.40 \\
\hline Public Finance & 25 & 2.59 & 8 & 0.99 & 0 & 0.00 & 0.00 & 6 & 0.24 \\
\hline Sociology & 24 & 2.48 & 25 & 3.08 & 61 & 2.13 & 2.44 & 10 & 0.41 \\
\hline Press & 20 & 2.07 & 4 & 0.49 & 6 & 0.21 & 1.50 & 4 & 0.20 \\
\hline Philosophy & 17 & 1.76 & 4 & 0.49 & 6 & 0.21 & 1.50 & 1 & 0.05 \\
\hline International Relation & 17 & 1.76 & 22 & 2.71 & 135 & 4.71 & 6.13 & 8 & 0.47 \\
\hline Archeology & 16 & 1.65 & 9 & 1.11 & 1 & 0.03 & 0.11 & 6 & 0.37 \\
\hline Geography & 11 & 1.14 & 49 & 6.03 & 343 & 11.96 & 7.00 & 5 & 0.45 \\
\hline Psychology & 11 & 1.14 & 71 & 8.74 & 442 & 15.41 & 6.22 & 10 & 0.90 \\
\hline Labor Economics & 9 & 0.93 & 22 & 2.71 & 49 & 1.71 & 2.22 & 2 & 0.22 \\
\hline Politics & 9 & 0.93 & 4 & 0.49 & 1 & 0.03 & 0.25 & 2 & 0.22 \\
\hline Social Services & 9 & 0.93 & 24 & 2.96 & 468 & 16.32 & 19.50 & 3 & 0.33 \\
\hline Art History & 6 & 0.62 & 3 & 0.37 & 1 & 0.03 & 0.33 & 3 & 0.50 \\
\hline Total & 967 & 100.0 & 812 & 100.0 & 2868 & 100.0 & 3.53 & 273 & 0.28 \\
\hline
\end{tabular}


Educational sciences included all the studies which were conducted by senators regarding any educational subjects. In linguistics, there were insufficient information and studies on other languages; therefore, only Turkish language and literature was included. In total, there were 967 social sciences senators in the given year and 273 of them means 28 per cent had at least one publication in WoS and 130 of them had citations. The senators in the realm of social sciences authored 812 publications in WoS and their number of citations to those publications was reported to be 2868. Figure 1 provides the number of WoS publications and citations.

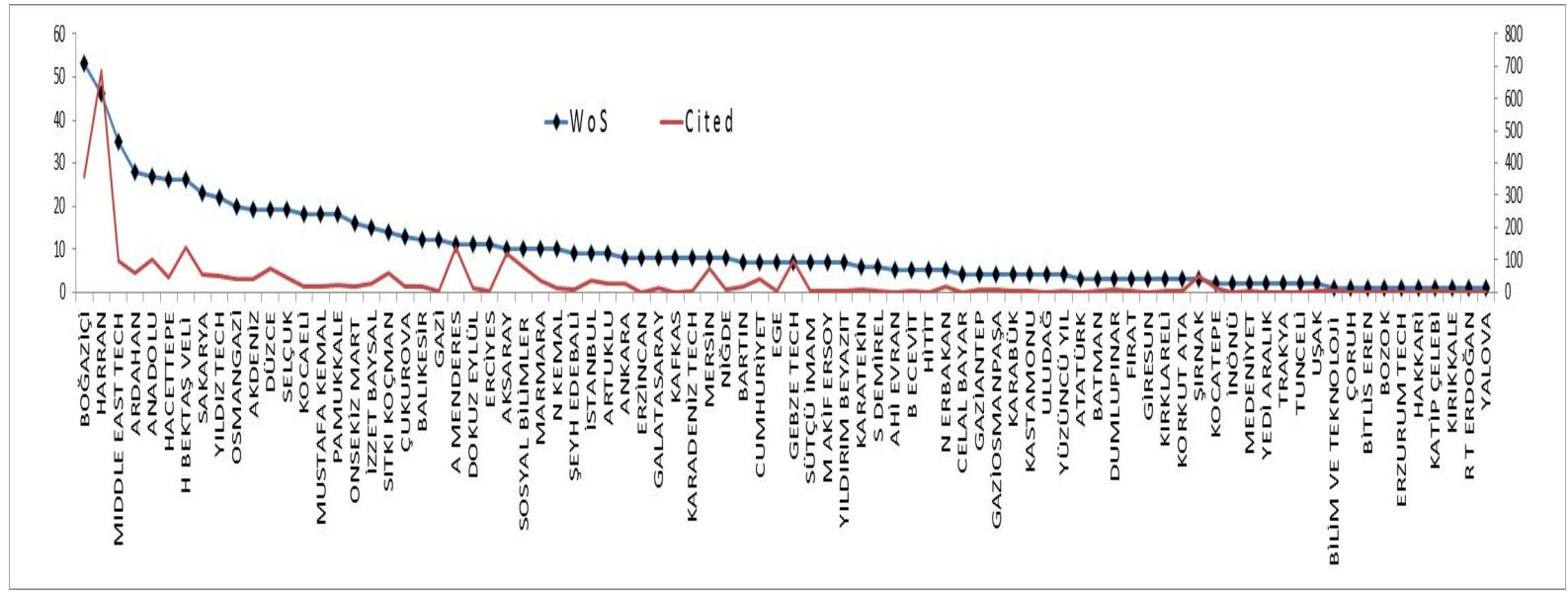

Figure 1. Distribution of WoS publications and citations over institutions

The number of publications decreased regularly and the value of each cited publications have remained fluctuant, yet. Table 3 shows the data regarding the senators included in this study. The scientific impact of those senators was presented in numerical order and percentages. The Pers\%, WoS\%, and cited\% columns gave the percentages of senators, WoS publications, and total WoS citations respectively in the related fields while Cited/WoS column represented the average number of citations of social sciences senators per WoS publication. The remaining columns represented the values which were presented in Table 3. The number of theologian administrators was about 167 which accounted for 17 per cent of all the senators and their rankings first. However, only 9 theologian administrators had $12 \mathrm{WoS}$ publications in total with only two WoS citations. The ratio of senators with WoS publications was 5.4 per cent for theologians and their share in WoS publications was less than 1.5 per cent. Therefore, the group of senators was located at the end of the list. Senators from public finance departments had the lowest performance in terms of the citations. From 25 senators in public finance departments, only six of them had a total of eight WoS publications and no citation belonged to their publications. The 16 per cent of all senators consisted of the senators in business departments which allocated the second place to itself. Among 154 senators from business departments, only 51 of them (about 33.1 per cent) had WoS publications which had the greatest value in Table 3 and only 23 of them had WoS citations. The total number of WoS publications by senators in business departments was 115 and the number of WoS citations to those publications was 216. Senators in economics departments formed 11per cent of all senators (about 108 administrators) and specialized the third rank. Among them, 41 of those senators (about 38 per cent) had publications in WoS while 25 of them had WoS citations. These senators had 133 publications in WoS and the number of WoS citations was 498 which 
was the highest value in the list. Kutlar, Kabasakal, and Ekici (2013) provided more detailed results about Turkish professors in economics.

Furthermore, among 68 senators who existed in departments of educational sciences, 38 of them had publications and 21 of them had citations. Genarally, this group of senators provided 157 WoS publications and 257 WoS citations. Even though educational administrators made up nearly 7 per cent of all administrators, they allocated only 19.3 per cent of WoS publications to themselves which meant nearly1.64 WoS citations for per publication in WoS.

In addition to economics departments, the highest number of citations specialized to the publications in three major fields of social services, psychology, and geography. The number of senators from the relevant fields was relatively low while the number of citations was quite high. The total number of senators from departments of social services was 9 and generally they had 24 publications. In the field of psychology, there were 11 senators who had 71 publications in general and only one of them did not have any publications. The amount of WoS citation divided by per WoS publications in social services, psychology, and geography was 19, 6.22, and 7, respectively. Personal qualities seemed to prevail in the departments of geography, psychology, and social services and only the senators in public finance, political science, art, history, law, and archeology departments could draw their attentions. Only public finance senators did not have any citations and the remaining senators in other relevant fields have at least one citation each. In addition to theologians, senators in law and public finance departments also occupied an adequate number of senate positions.

The last column in Table 3 provides the ratio of senators with publications in the WoS. According to Table 3, senators in psychology departments have the highest ratio and the number of citations received per publications in the WoS is below one in the eight fields. It also shows that the number of publications in the WoS for each senator is below one in the 13 fields. The lowest PerWoS/Wos indicators in Turkey belonged to law school administrators. There were 69 administrators in that field and only three of them had publications in the WoS and the number of citations for each of those publications was one. The level of competence in different fields such as theology, law, and public finance was lower than those from other social science fields among senators. Furthermore, the impact of such senators on their universities' rankings examined. The degree of association was measured by a correlation coefficient between senators' performances in three aforementioned fields. Table 3 represents their rankings. The results indicated that there wasnot significant relationship between their performances. In other words, neither negative nor positive correlation was observed between unproductive senators and their universities. However, technical universities such as Istanbul Technical, Middle East Technical, Gebze Technical, and Bogazici which did not employ senators from the relevant fields were considered as top-ranked universities. Table 4 shows that there were positive significant correlations between the variables.

According to Table 4, Pers only has significant correlation with WoS and PersWoS. Furthermore, there was a significant relationship between WoS and Cited variables at the 1 per cent level. There also was a statistically positive significant relationship between the variables, namely Cited/WoS and Cited. Moreover, other significant correlation did not report between other variables. Table 5 shows theologians in public universities. 
Table 4

Covariance Analysis: Correlation Matrix of Variables

\begin{tabular}{|c|c|c|c|c|c|}
\hline & Pers & WoS & Cited & Cited/WoS & PersWoS \\
\hline \multirow[t]{3}{*}{ Pers } & 1.00 \& & & & & \\
\hline & ----- & & & & \\
\hline & $----\vee$ & & & & \\
\hline \multirow[t]{3}{*}{ WoS } & 0.45 & 1.00 & & & \\
\hline & 2.20 & ----- & & & \\
\hline & 0.03 & ----- & & & \\
\hline \multirow[t]{3}{*}{ Cited } & 0.05 & 0.65 & 1.00 & & \\
\hline & 0.23 & 3.81 & ---- & & \\
\hline & 0.81 & 0.00 & ---- & & \\
\hline \multirow[t]{3}{*}{ Cited/WoS } & -0.26 & 0.09 & 0.72 & 1.00 & \\
\hline & -1.17 & 0.40 & 4.53 & ----- & \\
\hline & 0.25 & 0.68 & 0.00 & ---- & \\
\hline \multirow[t]{3}{*}{ PersWoS } & 0.68 & 0.88 & 0.41 & -0.09 & 1.00 \\
\hline & 4.08 & 8.35 & 1.96 & -0.41 & ----- \\
\hline & 0.00 & 0.00 & 0.06 & 0.68 & ----- \\
\hline
\end{tabular}

Included observations: 21 ; C Correlation, $\bullet$ T-statistic, $\bullet$ Probability

According to Table 5, the left column represents the list of universities that employ the highest number of theologians while the right column provides the list of universities where theologians have more publications. Table 5 also shows that Cumhuriyet and Suleyman Demirel employ the highest number of theologians in Turkey. However, none of those senators had publications in the WoS. Harran University employed a great number of theologians as well that were four administrators among them. The theologians at Harran University had 5 publications in the WoS. Senators at Harran University had five publications in the WoS and the senators from other seven universities only had one publication each. Among the senators at 109 public universities, only those in seven universities had at least one publication in the WoS and there was no overlap between the universities which employed the highest number of theologians and the universities that employed theologians with publications in the WoS but one exception.

Table 5

Theologians in Public Universities

\begin{tabular}{lcclc}
\hline Institutions & Pers & WoS & Institutions & WoS \\
\hline Cumhuriyet & 7 & 0 & Harran & 5 \\
Sdemirel & 7 & 0 & Ardahan & 1 \\
Hitit & 5 & 0 & Bozok & 1 \\
Coruh & 4 & 0 & Osmangazi & 1 \\
Ataturk & 4 & 0 & İnonu & 1 \\
Harran & 4 & 5 & Kirikkale & 1 \\
Ondokuzmayis & 4 & 0 & Makif Ersoy & 1 \\
R. Tayyip Erdogan & 4 & 0 & & \\
Şrnak & 4 & 0 & & \\
Usak & 4 & 0 & & \\
\hline
\end{tabular}

\section{Conclusion}

Higher education has gone through major reformation following the constitution of the Republic of Turkey in 1982. After the 1982s, many private and public universities were founded. This study investigated the number of social science senators' WoS publications and citations at public Turkish universities in 2014. There were 21 fields of study including 
educational sciences in 109 public universities. There were 967 social science senators in those public universities; however, only 273 of them had a total of 812 publications in the WoS. There were 25 universities among those 109 public universities where social science senators did not have any WoS publications. It is worth noting that there were 167 theologian administrators accounting for 17 per cent of all the senators and allocated the first rank so that the administrators in the department of business and economics could follow. Among theological college administrators and theologians, only 9 of them or 5 per cent of them had publications in the WoS. In terms of the average number of citations, public finance senators had the lowest performance.

The administrators in the business departments made up 16 per cent of all administrators and allocated the second rank. Among those 154 senators in business departments, only 51of them or 33 per cent of them had publications in the WoS which was considered as the greatest value. The total number of WoS publications was 115 and the number of citations to those publications was 216. In economics departments, from 108 administrators (about 11 per cent) only 41 of them (about 38 per cent) had publications in the WoS. The smallest values on the tables except for cited values belonged to the law senators. Among 69 senators, only 3 of them had publications in the WoS. The number of citations to the publications is one. There were 68 administrators from educational sciences departments and they had a total of $157 \mathrm{WoS}$ publications. The highest number of citations was related to the publications in the fields of geography, social services, and psychology. In the field of psychology, only 11 of the senators had a total of 71 publications and among this number only one person had no publications.

Furthermore, theologians and other senators in the departments such as public finance, political science, art history, law, and archeology could attract attention. Theologians did not have any citations while the senators in the remaining fields had one citation each. Also, senators from departments of theology, law, and public finance occupied more senate positions. It is worth to mention that the universities that offered a higher position for theologians did not have any WoS publications except for Harran University. Moreover, there was not any significant relationship between academically unproductive senators and their universities. However, technical universities such as Istanbul Technical, Middle East Technical, Gebze Technical, and Bogazici that did not employ senators from the relevant fields were considered as top-ranked universities in the list. Finally, further research could also be conducted to determine the scientific contributions of lower performing senators to their universities should be reevaluated.

\section{References}

Abbott, M., \& Doucouliagos, C. (2003). The efficiency of Australian universities: A data envelopment analysis. Economics of Education Review, 22(1), 89-97.

Agasisti, T., \& Dal Bianco, A. (2009). Reforming the university sector: Effects on teaching efficiency-evidence from Italy. Higher Education, 57(4), 477-498.

Ahn, T., Arnold, V., Charnes, A., \& Cooper, W. W. (1989). DEA and ratio efficiency analyses for public institutions of higher learning in Texas. Research in Governmental \& Nonprofit Accounting, 5, 165-185.

Athanassopoulos, A., \& Shale, E. (1997). Assessing the comparative efficiency of higher education institutions in the UK by means of data envelopment analysis. Education Economics, 5(2), 117-133.

Avkiran, N. K. (2001). Investigating technical and scale efficiencies of Australian universities through data envelopment analysis. Socio-Economic Planning Sciences, 35(1), 57-80. 
Bergseth, B., Petocz, P., \& Dahlgren, M. A. (2014). Ranking quality in higher education: Guiding or misleading? Quality in Higher Education, 20(3), 330-347.

Castano, M. C. N., \& Cabanda, E. C. (2007). Performance evaluation of the efficiency of Philippine private higher educational institutions: Application of frontier approaches. International Transactions in Operational Research, 14(5), 431-444.

Celik, O., \& Ecer, A. (2009). Efficiency in accounting education: Evidence from Turkish universities. Critical Perspectives on Accounting, 20(5), 614-634.

Cherchye, L., Abeele, P. V. (2005). On research efficiency: A micro-analysis of Dutch university research in economics and business management. Research Policy, 34(4), 495-516.

Coelli, T. J., Rao, D. S. P., \& Battese, G. E. (1998). Introduction to efficiency and productivity analysis. Boston: Kluwer Academic Publishers.

Daraioa, C., Bonaccorsi, A., \& Simar, L. (2015). Rankings and university performance: A conditional multi-dimensional approach. European Journal of Operational Research, 244(3), 918-930.

Flegg, A. T., \& Allen, D. O. (2007). Does expansion cause congestion? The case of the older British universities, $1994-2004$. Education Economics, 15(1), 75-102.

Johnes, J. (2006). Data envelopment analysis and its application to the measurement of higher education. Economics of Education Review, 25(3), 273-288.

Johnes, J., \& Yu, L. (2008). Measuring the research performance of Chinese higher education institutions using data envelopment analysis. China Economic Review, 19(4), 679-696.

Johnes, G., \& Johnes, J. (2009). Higher education institutions' costs and efficiency: Taking the decomposition a further step. Economics of Education Review, 28(1), 107-113.

Joumady, O., \& Ris, C. (2005). Performance in European higher education: A non-parametric production frontier approach. Education Economics, 13(2), 189-205.

Katharaki, M., \& Katharakis, G. (2010). A comparative assessment of Greek universities' efficiency using quantitative analysis. International Journal of Educational Research, 49(4/5), 115-128.

Kutlar, A., Kabasakal, A., \& Ekici, M. S. (2013). Contributions of Turkish academicians supervising PhD dissertations and their universities to economics: An evaluation of the 1990-2011 period. Scientometrics, 97(3), 639-658.

Lukman, R., Krajnc, D., \& Glavi, P. (2010). University ranking using research, educational, and environmental indicators. Journal of Cleaner Production, 18(7), 619-628.

Millot, B. (2014). International rankings: Universities vs. higher education systems. International Journal of Educational Development, 40, 156-165.

Ng, Y. C., \& Li, S. K. (2000). Measuring the research performance of Chinese higher education institutions: An application of data envelopment analysis. Educational Economics, 8(2), 139-156.

Ruiz, J. L., Segura, J. V., \& Sirvent, I. (2015). Benchmarking and target setting with expert preferences: An application to the evaluation of educational performance of Spanish universities. European Journal of Operational Research, 242(2), 594605.

Salerno, C. S. (2002). On the technical and allocative efficiency of research-intensive higher education institutions (Unpublised Doctoral dissertation). University Park, PA.: Pennsylvania.

Warning, S. (2004). Performance differences in German higher education: Empirical analysis of strategic groups. Review of Industrial Organization, 24(4), 393-408.

Worthington, A. C., \& Lee, B. L. (2008). Efficiency, technology and productivity change in Australian universities, 19982003. Economics of education review, 27(3), 285-298.

Yaisawarng, S., \& Ng, Y. C. (2014). The impact of higher education reform on research performance of Chinese universities. China Economic Review, 31, 94-105.

Zoghbi, A. C., Rocha, F., \& Mattos, E. (2013). Education production efficiency: Evidence from Brazilian universities. Economic Modelling, 31, 94-103. 